\title{
Methodology Optimization and Application for Measurement of Gaseous Elemental Mercury in the Amazon Atmosphere
}

\author{
Marcelo D. Almeida, ${ }^{* a, b}$ Rozane V. Marins, ${ }^{a}$ Heloisa H. M. Paraquetti ${ }^{a, b}$ and Luiz D. Lacerda ${ }^{a, b}$
}

${ }^{a}$ Instituto de Ciências do Mar, Universidade Federal do Ceará, Av. Abolição 3207, 60165-081 Fortaleza-CE, Brazil

${ }^{b}$ Departamento de Geoquímica, Universidade Federal Fluminense, Campus do Valonguinho, 24020-007 Niterói-RJ, Brazil

O objetivo desse trabalho foi otimizar uma metodologia semi-automática utilizando cartuchos comerciais preenchidos com ouro puro (Tekran Inc.) para a quantificação de mercúrio gasoso elementar em atmosfera tropical. O limite de detecção foi 0,020 $\pm 0,006 \mathrm{ng}$ de $\mathrm{Hg}$. Isso corresponde a limites de detecção variando entre 0,2 e $0,4 \mathrm{ng} \mathrm{m}^{-3}$, para volumes de amostragem entre 0,1 e $0,05 \mathrm{~m}^{3}$. A similaridade entre os 9 cartuchos foi avaliada. A avaliação do efeito da vazão de amostragem entre 0,4 e 2,0 $\mathrm{L} \mathrm{min}^{-1}$ não representou diferença. A capacidade máxima de retenção dos cartuchos (breakthrough) não foi alcançada nos experimentos com vazão de 1 ou $2 \mathrm{~L} \mathrm{~min}{ }^{-1}$, concentração de $\mathrm{Hg}$ de $25 \mathrm{ng} \mathrm{m}^{-3}$ e volume máximo de $150 \mathrm{~L}$. A condensação de água na superfície do ouro mostrou ser um problema, mas isso foi solucionado com o aquecimento do cartucho de amostragem a $60{ }^{\circ} \mathrm{C}$.

The aim of this study was to optimize a semi-automatic methodology using commercial pure gold cartridges (Tekran Inc.) to quantify gaseous elemental mercury (GEM) in the Amazon atmosphere. The detection limit was $0.020 \pm 0.006 \mathrm{ng} \mathrm{Hg}$. This corresponds to detection limits varying from 0.2 to $0.4 \mathrm{ng} \mathrm{Hg} \mathrm{m}^{-3}$, for field sample volumes ranging between 0.1 and $0.05 \mathrm{~m}^{3}$. The similarity between the 9 tested cartridges was evaluated. Under sampling flow rates varying between 0.4 and $2.0 \mathrm{~L} \mathrm{~min}^{-1}$ no difference among cartridges was observed. The maximum retention capacity of the cartridge (breakthrough) was not reached in experiments with flow rates of 1 or $2 \mathrm{~L} \mathrm{~min}^{-1}$, and with $\mathrm{Hg}$ concentration of $25 \mathrm{ng} \mathrm{m}^{-3}$ and maximum air volume of $150 \mathrm{~L}$. Water condensation on the gold surface showed to be a problem, but that was solved by heating the sample cartridge at $60^{\circ} \mathrm{C}$ during sampling.

Keywords: gaseous elemental mercury (GEM), atmospheric mercury, Amazon atmosphere, methodology optimization

\section{Introduction}

There are many available methods for atmospheric mercury sampling and measurement in the atmosphere. The procedure chosen depends on the resolution time, the mercury concentration and ambient interferents. ${ }^{1}$ Notwithstanding, to determine trace mercury concentrations in gaseous matrixes, such as in natural air, a pre-concentration phase is essential. Pre-concentration can be achieved by various forms, the most common are: absorption in liquid, such as a permanganate solution; ${ }^{2}$ solid adsorption, such as onto $\mathrm{coal}^{3,4}$ and amalgamation with metal surfaces, such as silver, gold or platinum. ${ }^{5,6}$

*e-mail: marcelo_dominguez@hotmail.com
After pre-concentration, detection techniques frequently used are cold vapor atomic absorption spectrometry (CVAAS) and cold vapor atomic fluorescence spectrometry (CVAFS). Both techniques detect mercury vapor $\left(\mathrm{Hg}^{0}\right)$. CVAFS is considered the preferred method due to its sensitivity, specificity and better linearity. Nowadays, the most used system (sampling and detection) is gold amalgamation onto small cartridges and CVAFS detection of the gaseous elemental mercury (GEM). The sampling and analysis of atmospheric mercury are made frequently only for total gaseous mercury (TGM), an operationally defined fraction that includes $\mathrm{Hg}$ species that pass through $0.45 \mu \mathrm{m}$ pore diameter filters or some other simple filtration device, such as quartz wool plugs, and is collected onto the gold. TGM is composed mainly of the GEM with minor contents of other $\mathrm{Hg}$ species, particularly $\mathrm{HgCl}_{2}$, 
$\mathrm{CH}_{3} \mathrm{HgCl}$ and $\left(\mathrm{CH}_{3}\right)_{2} \mathrm{Hg}$. In remote regions, where the concentrations of particulate mercury are generally very low, TGM corresponds to over $99 \%$ of the total mercury concentration in air. ${ }^{7,8}$

Most used automate instruments currently available to quantify TGM concentrations in atmospheric air are: the PSA-Sir Galahad II System, ${ }^{9}$ Tekran Inc., model 2537A, ${ }^{10}$ NIC-SP-3D ${ }^{11}$ and the Gardis mercury analyzer. ${ }^{12}$ All these equipments worked with pre-concentration by gold amalgamation. The two first equipments use detection by CVAFS while the others use CVAAS. Another instrument that uses CVAAS detection is the RA915+ by Lumex, ${ }^{13}$ but this does not use pre-concentration. Detection is possible because the RA915+ uses a 10-meter multipath optical cell and simultaneous Zeeman background correction. This combination eliminates interferences and provides the highest sensitivity in real-time, but the detection limit (about $2 \mathrm{ng} \mathrm{m}^{-3}$ ) is in general too high for studies in remotes areas. Pre-concentration systems can reach much lower detection limits, which are crucial to natural atmospheric mercury determinations. The annual average surface concentrations of TGM simulated with the global AER/EPRI chemical transport model showed range of 1.2 to $1.6 \mathrm{ng} \mathrm{m}^{-3}$ for remote areas. ${ }^{14}$ On the other hand, pre-concentration systems have longer response time, sometimes making difficult to evaluate short-term changes in mercury concentrations.

Gold cartridges are capable to sample TGM but AFS or AAS detectors can only detect GEM. Schroeder and Jackson ${ }^{15}$ proposed an analytical system able to detect all "mercury species of environmental interest" (operationally defined as TGM). The key step of this analytical system is the application of a pyrolysis tube heated at $900{ }^{\circ} \mathrm{C}$ between the sampling cartridge and the analytical cartridge. Pyrolytic decomposition releases GEM that can be readily determined by AFS or AAS. Currently the systems do not use pyrolytic decomposition for TGM determination but automatic instruments, such as the Tekran Inc., 2537A, is described as a TGM analyzer. ${ }^{10}$ There is a debate as to whether it measures TGM or just GEM. However many researchers have used this measurement as TGM. ${ }^{16-20}$ In this work the sampling and analytical cartridges were quickly heated at $900{ }^{\circ} \mathrm{C}$ during the desorpion phase. However, some preliminary tests (data under preparation) have suggested that reactive gaseous mercury (RGM), which mostly includes $\mathrm{HgCl}_{2}, \mathrm{CH}_{3} \mathrm{HgCl}$ and $\left(\mathrm{CH}_{3}\right)_{2} \mathrm{Hg}$, crosses the cartridge before the pyrolytic temperature is reached. Thus mercury concentrations in this work are better described as GEM.

Although some studies have reported on $\mathrm{Hg}$ concentrations in the Amazon atmosphere, the sampling, pre-concentration and detection procedures used until now were not fully tested for the natural interferents, such as humidity, present in ambient air, in particular in tropical regions. Only few studies has tested for the effect of humidity on gold-coated, quartz, cartridges..$^{21,22}$ Therefore the aim of this study was to optimize a semi-automatic methodology using pure gold cartridges (Tekran Inc., N. 35-26500-00) to quantify gaseous elemental mercury (GEM) in the Amazon atmosphere. The effect of the high relative humidity and the sampling air volume were investigated in laboratory experiments. Pure gold cartridges were tested for the GEM sampling and detection under a standard elemental mercury atmosphere under typical environmental conditions and different collection flows. Finally, GEM measurements were actually made in the filed at Rondônia University campus located near to Porto Velho city, state of Rondônia, Western Amazon.

\section{Experimental}

The method is based on gold cartridge amalgamation and subsequent analysis using CVAFS. Sampling cartridges are routinely used in the field for collection of GEM. Once in the laboratory, the cartridges were thermally desorbed to release the collected GEM. The analysis were made using a double amalgamation system connected to a fluorescence detector. ${ }^{23}$ In this procedure the sampling cartridge is installed in series with an analytical cartridge in the carrier flow (Argon) that carries the GEM to the fluorescence detector. The argon flow is regulated by a build-in mass flow control in the Tekran Inc., 2500. The heating for the release of the amalgamated GEM is obtained with a Ni-Cr resistance by feeding a variac (17 Vac, $10 \mathrm{amps}$ ) for $30 \mathrm{~s}$ reaching a maximum temperature of $900{ }^{\circ} \mathrm{C}$. In the first stage the GEM is thermally desorbed from the first cartridge (sampling cartridge) and is carried through a Teflon pipe at the second cartridge (analytical cartridge). The analytical cartridge is then quickly (30 s) heated to $900{ }^{\circ} \mathrm{C}$ and the GEM is carried to the detector by $80 \mathrm{~mL} \mathrm{~min}^{-1}$ argon flow. The system was assembled with the fluorescence detector, a Tekran Inc., model 2500, connected to a computer through a RS-232c multimeter interface (Minipa Ms-60). The data were captured and analyzed by an especially designed program (programming language C\# NET 1.1) for this function. The program detects and calculates peak area and maximum and minimum values. The opening and closing of the solenoid valve that controls the argon flow, as well as the heating and cooling of cartridges, were controlled by a programmable timer (Chrontrol XT). Figure 1 illustrates the double amalgamation system used for GEM analysis, structuralized for system calibration. By changing the port of injection by the sampling cartridge the system is mounted for sampling cartridges analysis. 


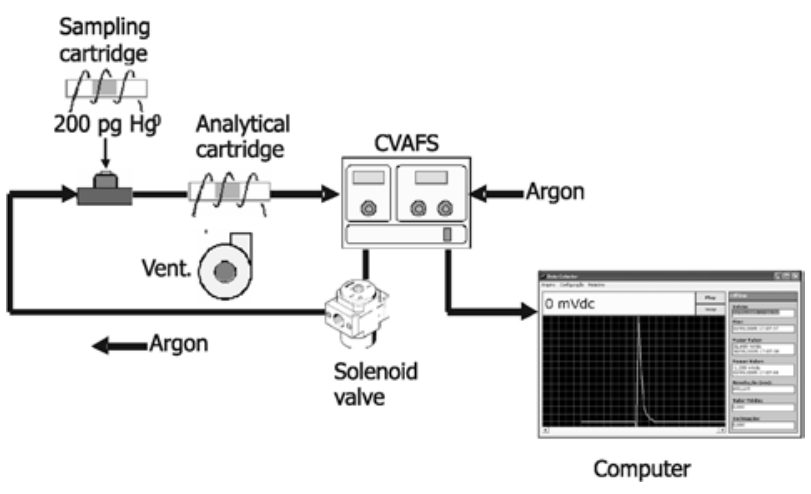

Figure 1. Calibration and analytical systems used in the present study.

\section{System calibration}

The GEM concentration analytical detection system was calibrated by saturated mercury vapor injection method. ${ }^{6}$ The saturated mercury vapor was supplied by a chamber containing $5 \mathrm{~mL}$ of mercury. The chamber is kept under ambient atmospheric pressure by a small orifice that has access to ambient conditions through a capillary. The chamber is placed in a container with water and the temperature is monitored. The vapor pressure of mercury as a function of temperature is well documented. The amount of mercury contained per unit volume at a given temperature is a well known function that is available on the following numerical formulation. ${ }^{24}$

Conc. $\mathrm{Hg}^{0}=\left(\frac{\mathrm{A}}{\mathrm{T}}\right) \times 10^{-\left(-\mathrm{B}+\left(\frac{\mathrm{C}}{\mathrm{T}}\right)\right)}$

where Conc. $\mathrm{Hg}^{0}$, mercury concentration (pg $\mu \mathrm{L}^{-1}$ ); $\mathrm{T}$, temperature (K); A, 3216522.61; B, 8.134459741; C, 3240.871534.

Thus, different saturated mercury vapor micro-volumes are removed through one septum using a gas-tight Teflon micro-syringe (Hamilton $® 81030$ ). The analytical system was calibrated by injection of known amounts of gaseous elemental mercury in the argon flow carried to the analytical cartridge and, after heating, to the detector (Figure 1). The calibration curves were built on a mass basis and final concentrations were calculated using the field volume data. The instrument was daily calibrated with a five point linear standard curve ( $\mathrm{r}$ value $>0.995$ ).

\section{Field sampling cartridge}

The air sampling used pure gold cartridges (Tekran Inc., 35-26500-00). These cartridges consist of quartz pipes (4 millimeters of internal diameter, 6 millimeters of external diameter and a length of $13 \mathrm{~cm}$ ) with approximately one centimeter filled with small pure gold balls. These cartridges are closed with Teflon plugs that are removed only at the sampling moment.
The sampling was made by connecting the sampling cartridge to a computerized sampling pump URG-300002BA regulated for $1.5 \mathrm{~L} \mathrm{~min}^{-1}$ and a $0.45 \mu \mathrm{m}$ Millipore filter (MILLEX - FG 50) to prevent against inlet water drops and particulate matter. All cartridges were submitted to heating at $900{ }^{\circ} \mathrm{C}$ prior to utilization for eliminating any traces of $\mathrm{Hg}$. The cartridges were only taken to the field when zero reading was obtained.

\section{Standard mercury vapor atmosphere}

For the accomplishment of the tests of the efficiency of the 9 cartridges under the sampling conditions it was necessary to use a constant $\mathrm{Hg}^{0}$ concentration source. The first test was accomplished by using an equipment with a permeation tube (VICI Metronics Dynacalibrator®). However, the equipment produced too high mercury concentrations. The solution to the problem was to use a Teflon ${ }^{\circledR}$ sampling bag for the dilution of known mercury concentrations.

Standard mercury atmosphere simulations were made by the dilution of saturated mercury vapor in a Teflon ${ }^{\circledR}$ sampling bag of $350 \mathrm{~L}$ volume. The air used to prepare the standards was pumped through an active carbon filter, which virtually absorbs all $\mathrm{Hg}$ eventually present. To reach the desired diluted gaseous mercury concentrations, we controlled the $\mathrm{Hg}$-free air total volume with a flowmettertotalizer (GFM171 of AALBORG) and injected known volumes of saturated mercury vapor with a micro-syringe (Hamilton® 81030).

\section{Cartridges test system}

The cartridge test system is the system used for all tests. The system is composed of an air source with known $\mathrm{Hg}$ concentration (sampling bag) and cartridges in parallel for comparison of different temperatures and humidity or simply duplicate measurements, and cartridges in series to test the overflow. The sampling unit was assembled with a computerized pump (URG-3000-02BA) and flowmetter with totalizer (GFM171 of AALBORG) together with switching and flow regulator valves. The sampling cartridges were connected to the sampling unit and to sampling bag with standard mercury atmosphere simulations. The scheme is shown in Figure 2. All the tests were made with that configuration.

\section{Statistical analyses}

To avoid assuming a given statistical distribution of the obtained values, the nonparametric Kruskal-Wallis 


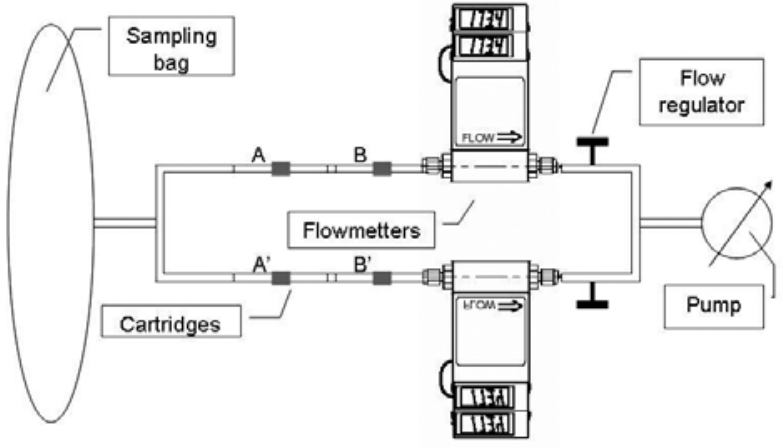

Figure 2. Schematic representation of system used to test cartridges.

ANOVA, Median Test, Sign test and Wilcoxon matched pairs test were used to test for differences between two data sets. The statistical significance was tested at a p-level of 0.05 or 0.01 . The Statistica 7.0 by StatSoft was used for the statistical tests. ${ }^{25}$

\section{Results and Discussion}

\section{Limit of detection of the method for GEM measurement}

There are several ways to calculate detection limits. A quick way is simply to divide three times the standard deviation of the field blank by the calibration curve slope and additionally divide this result by the sampling air volume. ${ }^{26}$ The field blank consists of sampling cartridges that are taken to the field but are not submitted to sampling. The field blank did not returned detectable values during the entire sampling period. Thus the analytical calibration curve was used to calculate the detection limit according to Miller and Miller. ${ }^{27}$ Under the described operational conditions, the detection limit was $0.020 \pm 0.006 \mathrm{ng} \mathrm{Hg}(\mathrm{n}=3)$. This corresponds to detection limits varying from 0.2 to $0.4 \mathrm{ng} \mathrm{Hg} \mathrm{m}^{-3}$, for sampling volumes varying between 0.1 and $0.05 \mathrm{~m}^{3}$, which are well below the reported background TGM concentrations measured in many different parts of the world. For example, background TGM concentration for Western Europe is around $1.5 \mathrm{ng} \mathrm{Hg} \mathrm{m}^{-3} .{ }^{28}$ Over the Atlantic Ocean, TGM concentrations vary from 1.02 to $2.31 \mathrm{ng} \mathrm{m}^{-3}$, with the highest concentrations found in the northern hemisphere. ${ }^{18,19}$ In the Amazon region very few data on TGM in the atmosphere distant from mine areas are available. However, Amouroux et al. ${ }^{29}$ measured an average TGM concentration of $2.8 \pm 1.4 \mathrm{ng} \mathrm{m}^{-3}$ for a 24 h-cycle in lake Petit Saut, in French Guyana. Fadini and $\mathrm{Jardim}^{30}$ reported a median value of $1.3 \mathrm{ng} \mathrm{m}^{-3}$ in the Negro River basin. Artaxo et al..$^{31}$ reported concentrations ranging from $0.5-2 \mathrm{ng} \mathrm{m}^{-3}$ in air samples collected from an airplane over the Amazon. With such concentrations, the employment of a minimum sample volume of about $0.05 \mathrm{~m}^{3}$ is probably sufficient for detection.

\section{Similarity between cartridges}

To work with different sample cartridges it is necessary to test if all the 9 cartridges used showed the same collecting efficiency. To make this test all 9 cartridges were submitted to a known gaseous mercury concentration. The mounted system for this test is presented in Figure 2. Each cartridge was tested 16 times. Figure 3 shows the Box whisker plot with average, standard error and standard deviation of the concentrations recovered by each cartridge. The KruskalWallis ANOVA by Ranks, Median Test and subsequent Multiple Comparisons $\mathrm{p}$ values were used to compare $(\mathrm{p}<0.05 ; \mathrm{n}=16)$ the mercury concentrations of the nine cartridges. Only a cartridge differed from the others by presenting extremely low recovery and was not used in the following tests.

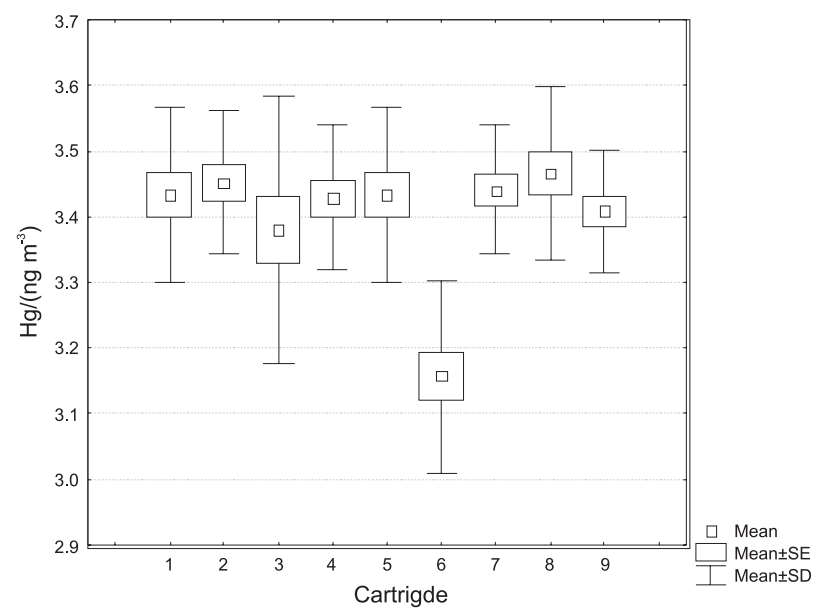

Figure 3. Box and whisker plot showing the GEM concentration recovery of each cartridge used in this study.

\section{Sampling flow evaluation}

Automated methods typically use a sampling flow varying from 1 to $1.5 \mathrm{~L} \mathrm{~min}^{-1}$., 10,12 Thus, a short sampling time (5 or $10 \mathrm{~min}$ ) confers enough volume for mercury detection. Manual methods generally use air flows of approximately $0.5 \mathrm{~L} \mathrm{~min}^{-1} .^{32}$ Lower sampling flows can be interesting for large sampling intervals but are not efficient for short sampling periods. Thus a range of air flows between 0.4 and $2.0 \mathrm{~L} \mathrm{~min}^{-1}$ with sampling volume of $10 \mathrm{~L}$ was used to analyze a constant GEM concentration (Figure 4). The Kruskal-Wallis ANOVA by Ranks, Median Test and subsequent Multiple Comparisons $\mathrm{p}$ values were used to compare the air flow rate. Although the highest air 
flows seem to have a lower recovery, the test did not show any significant difference $(\mathrm{p}<0.05 ; \mathrm{n}=6)$ within the group of cartridges.

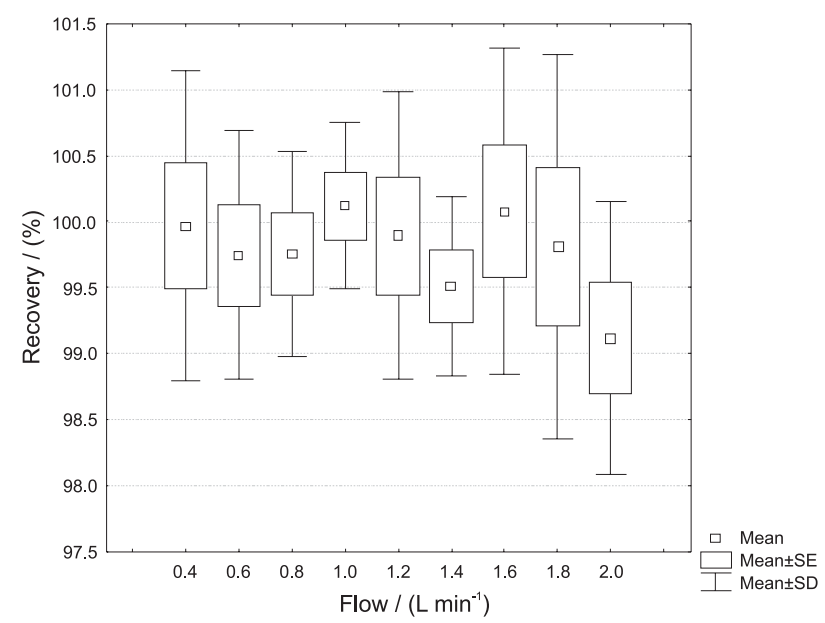

Figure 4. Box and whisker plot of the GEM recovery (\%) under different sampling flows.

\section{Cartridges breakthrough evaluation}

Breakthrough (overflow) is defined as $5 \%$ of the collected mercury amount in the first cartridge that is find in the second cartridge when assembled in series. ${ }^{33}$ The sampling time and the air volumes must be enough to make possible trustworthy mercury concentration analysis. However, volumes can not be large enough to cause breakthrough. The cartridges in general possess very large surface areas. Theoretically, gold has the capacity to absorb $1 \mu \mathrm{g} \mathrm{Hg} \mathrm{cm}^{-2}$. Therefore, a cartridge of approximately $20 \mathrm{~cm}^{2}$ of gold area would be able to absorb $20 \mu \mathrm{g}$ of mercury. ${ }^{24}$ However, an increase of the flow can quickly result in cartridge overflow. The breakthrough of pure gold cartridge of a constant concentration of GEM was studied as a function of sampling flow rate $\left(1 \mathrm{~L} \mathrm{~min}^{-1}\right.$ and $\left.2 \mathrm{~L} \mathrm{~min}^{-1}\right)$ and volume sampled. In both tests, the GEM concentration in sampled air was ca. $25 \mathrm{ng} \mathrm{Hg} \mathrm{m}^{-3}$.

For the breakthrough test, two cartridges were placed in series and known volumes of air were passed through them. Figure 2 shows the general system configuration to test for breakthrough volume. With this arrangement, mercury breakthrough is detected with a significant mercury amount in the second cartridge. In the first test a flow of $1 \mathrm{~L} \mathrm{~min}^{-1}$ was used and a maximum sample volume of $150 \mathrm{~L}(2 \mathrm{~h}$ and $30 \mathrm{~min}$ ). Only $1 \mathrm{pg}$ of $\mathrm{Hg}^{0}$ (a value below the detection limit and therefore showing large uncertainty) was detected in the second cartridge after the sampling of $120 \mathrm{~L}$. After $2 \mathrm{~h}$ and $10 \mathrm{~min}$ or $130 \mathrm{~L}, 16 \mathrm{pg}$ of $\mathrm{Hg}^{0}$ (or only $0.5 \%$ of the total $\mathrm{Hg}$ mass added to the system) were detected in the second cartridge. Following periodical additions of larger air volumes, the mercury mass in the second cartridge grew approximately in the rate of $0.28 \mathrm{pg}$ per additional liter of air (Figure 5a). The experiment was repeated using a flow of $2 \mathrm{~L} \mathrm{~min}^{-1}$. The volume varied from 10 up to $150 \mathrm{~L}$. After $75 \mathrm{~L}$ the collected $\mathrm{Hg}$ mass in the second cartridge started to increase in a rate of $0.34 \mathrm{pg}$ per additional liter of air (Figure 5b).

Breakthrough of the cartridge was not reached in any of the experiments, with less than $1 \%$ of the $\mathrm{Hg}$ passing to the second cartridge. However ambient factors such as humidity can affect the collection and therefore the nominal breakthrough of the cartridge.
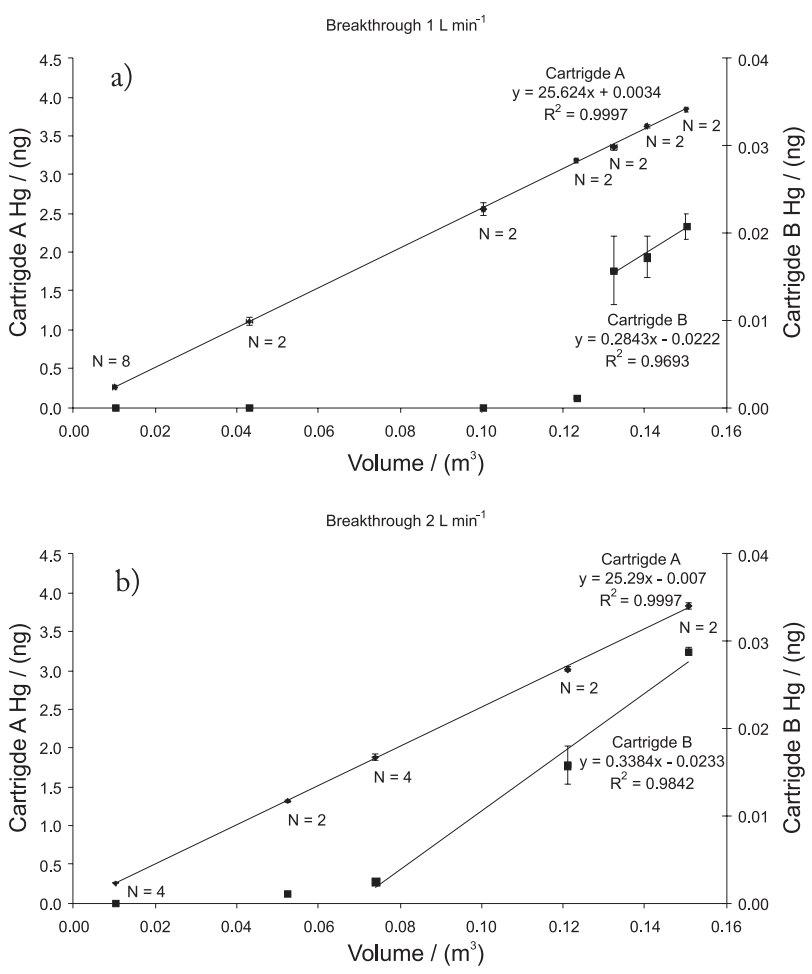

Figure 5. Scatter plot of mercury mass versus sampling volume at 1 and $2 \mathrm{~L} \mathrm{~min}^{-1}$ flow (a and b respectively) for breakthrough assessment.

\section{Cartridge passivation by humidity}

Under the determined conditions, the cartridge breakthrough can occur in smaller sampling volumes of that recommended in the laboratory tests. This is generally due to the presence of trace constituents in air that obstruct the gold surface. Possible contaminants are polycyclic aromatic hydrocarbons, water vapor, organic compounds and inorganic species formed through atmospheric reactions (for example: $\left(\mathrm{NH}_{4}\right)_{2} \mathrm{SO}_{4}$ ). Marins et al. ${ }^{21}$ showed that humidity is a key factor in the determination of mercury breakthrough. Under humidity above of $80 \%$ the collecting capacity of gold-covered annular denuders, used by those authors, can decrease to 
about ten times. Humidity is only a problem when water condenses on the denuder surface clogging the gold, which can easily be avoided by heating the denuders during sampling.

The breakthrough of a constant concentration of GEM (4.7 $\mathrm{ng} \mathrm{Hg} \mathrm{m}^{-3}$ ) through the gold cartridge as a function of sampling parameters including temperature and humidity was investigated. To test for the effect of humidity on cartridge efficiency, two cartridges were placed in parallel collecting the same standard mercury atmosphere. One of the cartridges was keep cooled at approximately $10^{\circ} \mathrm{C}$ and the other in ambient temperature (about $30^{\circ} \mathrm{C}$ ). At ambient temperature the relative humidity was approximately $70 \%$, but in the cooled cartridge the relative humidity reached $100 \%$, easily causing condensation. Before mercury determination in the cartridge, a dryer stage was performed. This stage consists in heating the cartridge at $60{ }^{\circ} \mathrm{C}$ for 10 min under a dry argon flow without any mercury loss. Sign Test and Wilcoxon Matched Pairs Test were used to compare the two dependent samples ( $n=14$ pairs). The tests indicate difference $(\mathrm{p}<0.01)$ between the pairs. The recovery in the cooled cartridge $(71.1 \pm 23.3 \%)$ was smaller than in the cartridge under ambient temperature $(99.9 \pm 2.50 \%)$.

Humidity can also be a problem during the detection phase. Extreme humidity in the optical pathway causes a gradual loss of sensitivity and the variation of the baseline. ${ }^{21}$ In fact the baseline increases when the humidity enters into the cell. Therefore it is recommended to keep the cartridge warm during sampling. However extreme heating can cause problems in the sampling. Aeschliman and Norton ${ }^{34}$ compared sampling efficiency as a function of temperature and reported that the amount of captured $\mathrm{Hg}^{0}$ at $200{ }^{\circ} \mathrm{C}$ was approximately $80 \%$ of the $\mathrm{Hg}^{0}$ captured at ambient temperature, and this percentage diminished quickly when temperature increased to $300{ }^{\circ} \mathrm{C}$. At this temperature only $3 \%$ of the $\mathrm{Hg}^{0}$ was successfully captured.

To test if heating the cartridge to $60{ }^{\circ} \mathrm{C}$ would affect sampling efficiency a similar system to that in Figure 2, was built with two pairs of cartridges mounted in parallel. A cartridge of the first pair (A') was kept warm at $60^{\circ} \mathrm{C}$ while cartridge A and the other pair (B and B') were kept at ambient temperature. The sampling flow was $2 \mathrm{~L} \mathrm{~min}^{-1}$ and the volume ranged from 10 to $150 \mathrm{~L}$, with GEM concentrations of approximately $30 \mathrm{ng} \mathrm{m}^{-3}$. After $75 \mathrm{~L}$ of sampling, the mercury content in the second cartridge pair (B and B') was similar roughly increasing at a rate of about $0.4 \mathrm{pg} \mathrm{L}^{-1}$, indicating that heating at $60^{\circ} \mathrm{C}$ not only avoided water condensation but also has no effect on GEM capture efficiency (Figure 6).

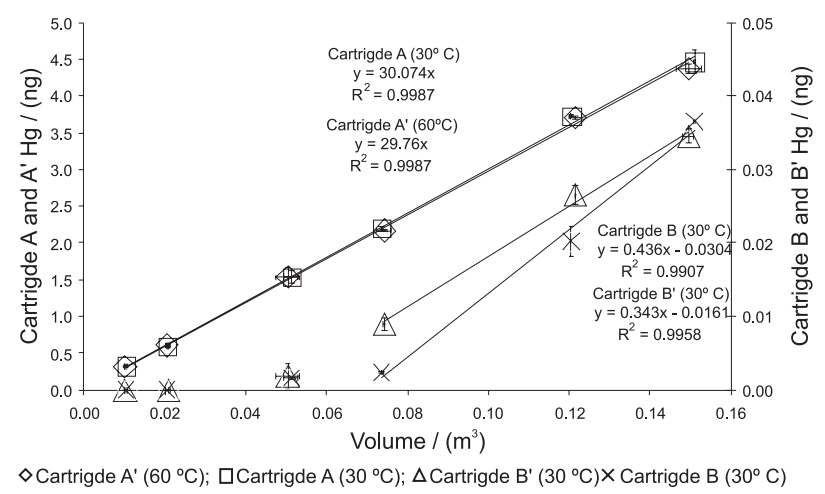

Figure 6. Scatter plot of mercury mass versus sampling volume at $2 \mathrm{~L}$ $\mathrm{min}^{-1}$ flow for breakthrough assessment with one cartridge keept warm at $60{ }^{\circ} \mathrm{C}$.

Gaseous elemental mercury measurements in the Amazon atmosphere

After optimization, GEM measurements were carried on in Porto Velho City, State of Rondônia, Western Amazon. Two cycles of $24 \mathrm{~h}$, one in a deforested, grassland area and the other in the forest, were monitored. In the deforested area measurements were taken every $35 \mathrm{~min}$, with $30 \mathrm{~min}$ for pre-concentration and 5 min for changing the cartridge. In the forest each measurement was taken every $40 \mathrm{~min}$, with $30 \mathrm{~min}$ for pre-concentration and $10 \mathrm{~min}$ to change the cartridge. The laboratory nearness made possible high time resolution, which is very important for the observation of the relationship between GEM concentration and meteorological parameters (Humidity and temperature were measured in situ by the sensor WE600 and WE700 connected to a datalogger GL400 of Global Water).

The sampling cartridges were kept heated at $60{ }^{\circ} \mathrm{C}$ during the sampling to eliminate condensation and passivation of the gold surface. The sampling flow was $1.5 \mathrm{~L} \mathrm{~min}^{-1}$ and the total volume of each pre-concentration step was approximately $45 \mathrm{~L}$.

The average GEM concentration obtained in the forest was $0.8 \pm 0.2 \mathrm{ng} \mathrm{m}^{-3}(\mathrm{n}=19)$ and $0.8 \pm 0.1 \mathrm{ng} \mathrm{m}^{-3}$ $(\mathrm{n}=17)$ during day and night respectively. Whereas in the deforested area the average obtained was $1.5 \pm 0.3 \mathrm{ng} \mathrm{m}^{-3}$ $(\mathrm{n}=22)$ and $1.8 \pm 1.0 \mathrm{ng} \mathrm{m}^{-3}(\mathrm{n}=20)$ during day and night, respectively. The average of the $24 \mathrm{~h}$-cycle was $0.8 \pm 0.1 \mathrm{ng} \mathrm{m}^{-3}(\mathrm{n}=36)$ with air humidity $100 \pm 8.8 \%$ and $1.6 \pm 0.8 \mathrm{ng} \mathrm{m}^{-3}(\mathrm{n}=42)$ with air humidity $89 \pm 20 \%$, for forest and deforested area, respectively. The sampling volume and flow rate used (about $45 \mathrm{~L}$ and $1.5 \mathrm{~L} \mathrm{~min}^{-1}$ ) were sufficient to detect the GEM.

These concentrations were very low when compared with other measured values reported a decade ago in the Amazon, when total mercury concentrations in the atmosphere of urban areas in Alta Floresta, Southern 
Amazon, ranged from 10 to 5,800 $\mathrm{ng} \mathrm{m}^{-3}$, and with indoor gold dealer's shops atmosphere ranging from 141 up to $40,600 \mathrm{ng} \mathrm{m}^{-3} \cdot{ }^{35}$ In the urban area of Poconé City, Marins and co-workers ${ }^{36,37}$ reported concentrations ranging from $<140$ up to $1,900 \mathrm{ng} \mathrm{m}^{-3}$ close to gold dealers shops. Lodenius and $\mathrm{Malm}^{38}$ found mercury concentration ranging from $<140$ to $500 \mathrm{ng} \mathrm{m}^{-3}$ close to the Teotônio Waterfalls and from $<20$ up to $660 \mathrm{ng} \mathrm{m}^{-3}$ in urban areas far from mining areas. They have also reported total $\mathrm{Hg}$ concentrations ranging from 450 to $7,500 \mathrm{ng} \mathrm{m}^{-3}$ in urban areas close to gold-Hg amalgam smelting sites in the Porto Velho-RO, and up to $60,000 \mu \mathrm{g} \mathrm{m}^{-3}$ when smelting occurred in the field without using retorts. These higher measurements however, included sometimes total $\mathrm{Hg}$ species present in air, including particulate-Hg, since all used air bubbling through an oxidizing permanganate solution, which also results in extremely high detection limits. Also all these results were obtained during the peak of gold mining and therefore higher of $\mathrm{Hg}$ emission to Amazon atmosphere. More recently, studies using gold amalgamation pre-concentration techniques similar to ours have produced similar results to those from Porto Velho presented here. Magarelli and Fostier, ${ }^{39}$ reported average atmospheric TGM concentrations in the Negro River basin, northern Amazon, of $1.4 \pm 0.9 \mathrm{ng} \mathrm{m}^{-3}$ and $0.4 \pm 0.2 \mathrm{ng} \mathrm{m}^{-3}$ for forest and deforested sites, respectively. These values although similar to those obtained in the present work showed higher $\mathrm{Hg}$ concentrations in forest rather than in deforested areas. Amouroux et al. ${ }^{29}$ also reported TGM concentrations of $2.8 \pm 1.4 \mathrm{ng} \mathrm{m}^{-3}$ in a forest area of French Guiana, whereas Fadini and $\mathrm{Jardim}^{30}$ reported average TGM concentrations in air samples from forest areas at the Negro River basin of $1.3 \mathrm{ng} \mathrm{m}^{-3}$.

\section{Conclusions}

The detection limit of the proposed procedure was $0.020 \pm 0.006 \mathrm{Hg}$ ng as GEM. This corresponds to detection limits varying from 0.2 to $0.4 \mathrm{ng} \mathrm{Hg} \mathrm{m}^{-3}$, for field sample volumes between 0.1 and $0.05 \mathrm{~m}^{3}$. Sampling flow rates between 0.4 and $2.0 \mathrm{~L} \mathrm{~min}^{-1}$ did not show any difference in cartridge performance, but the highest flow rate seems to results in a poorer recovery, although not statistically significant. Sampling flow rate of $1.5 \mathrm{~L} \mathrm{~min}^{-1}$ was chosen optimal since enables fast sampling and showed no effect on cartridge performance. Cartridge breakthrough was not reached in any of the experiments, with less than $1 \%$ of the total $\mathrm{Hg}$ mass passing to the second cartridge with flow rates of 1 or $2 \mathrm{~L} \mathrm{~min}^{-1}$, GEM concentration of up to $25 \mathrm{ng} \mathrm{m}^{-3}$ and maximum air volume of $150 \mathrm{~L}$. Water condensation on the gold surface showed to be a problem, but it was solved by keeping the sampling cartridge heated to $60{ }^{\circ} \mathrm{C}$.
This heating procedure showed no effect on GEM capture by the cartridges.

GEM measurements were made in Porto Velho City, Western Amazon, and the average of the $24 \mathrm{~h}$-cycle was $0.8 \pm 0.1 \mathrm{ng} \mathrm{m}^{-3}(\mathrm{n}=36)$ and $1.6 \pm 0.8 \mathrm{ng} \mathrm{m}^{-3}(\mathrm{n}=42)$ for forest and deforested areas, respectively. Sampling volume and flow rates of about $45 \mathrm{~L}$ and $1.5 \mathrm{~L} \mathrm{~min}^{-1}$ respectively, showed to be sufficient to detect the GEM present in the Amazon atmosphere, whereas heating the cartridge during sampling avoided water vapor condensation.

\section{Acknowledgments}

We thank Pedro A. P. Pereira and Jailson B. de Andrade for helping with the calibration equipment and discussion of earlier results of this experiment. Thanks are also due to the National Counsel for Technological and Scinentific Development (CNPq) for financial support of this research, and the Brazilian Federal Agency for Support and Evaluation of Graduate Education (CAPES) for providing grants to the author.

\section{References}

1. Ebinghaus, R.; Jennings, S. G.; Schroeder, W. H.; Berg, T.; Donaghy, T.; Guentzel, J.; Kenny, C.; Kock, H. H.; Kvietkus, K.; Landing, W.; Muhleck, T.; Munthe, J.; Prestbo, E. M.; Schneeberger, D.; Slemr, F.; Sommar, J.; Urba, A.; Wallschlager, D.; Xiao, Z.; Atmos. Environ. 1999, 33, 3063.

2. Drew, R. G.; King, E.; Analyst 1957, 82, 461.

3. Braman, R. S.; Johnson, D. L.; Environ. Sci. Technol. 1975, 9 , 366.

4. Johnson, D. L.; Braman, R. S.; Environ. Sci. Technol. 1974, 8, 1003.

5. Barghigiani, C.; Ristori, T.; Cortopassi, M.; Environ. Technol. 1991, 12, 935.

6. Dumarey, R.; Dams, R.; Hoste, J.; Anal. Chem. 1985, 57, 2638.

7. Munthe, J.; Berg, T.; Atmos. Environ. 2001, 35, 5379.

8. Munthe, J.; Wangberg, I.; Pirrone, N.; Iverfeldt, A.; Ferrara, R.; Ebinghaus, R.; Feng, X.; Gardfeldt, K.; Keeler, G.; Lanzillotta, E.; Lindberg, S. E.; Lu, J.; Mamane, Y.; Prestbo, E.; Schmolke, S.; Schroeder, W. H.; Sommar, J.; Sprovieri, F.; Stevens, R. K.; Stratton, W.; Tuncel, G.; Urba, A.; Atmos. Environ. 2001, 35, 3007.

9. http://www.psanalytical.com/; accessed in November 2007.

10. http://www.tekran.com/; accessed in November 2007.

11. http://www.hg-nic.com/english/sp-3d.html; accessed in November 2007.

12. Urba, A.; Kvietkus, K.; Sakalys, J.; Xiao, Z.; Lindqvist, O.; Water, Air, Soil Pollut. 1995, 80, 1305. 
13. http://www.lumex.biz/product/ra915.shtml; accessed in November 2007.

14. Lohman, K.; Seigneur, C.; Gustin, M.; Lindberg, S.; Appl. Geochem. 2008, 23, 454.

15. Schroeder, W. H.; Jackson, R.; Chemosphere 1984, 13, 1041.

16. Bahlmann, E.; Ebinghaus, R.; J. Phys. IV 2003, 107, 99.

17. Kock, H. H.; Bieber, E.; Ebinghaus, R.; Spain, T. G.; Thees, B.; Atmos. Environ. 2005, 39, 7549.

18. Temme, C.; Einax, J. W.; Ebinghaus, R.; Schroeder, W. H.; Environ. Sci. Technol. 2003, 37, 22.

19. Temme, C.; Slemr, F.; Ebinghaus, R.; Einax, J. W.; Atmos. Environ. 2003, 37, 1889.

20. Zhang, H. H.; Poissant, L.; Xu, X. H.; Pilote, M.; Atmos. Environ. 2005, 39, 7481.

21. Marins, R. V.; de Andrade, J. B.; Pereira, P. A. D.; Paiva, E. C.; Paraquetti, H. H. M.; J. Environ. Monit. 2000, 2, 325.

22. Magarelli, G.; Fostier, A. H.; Quim. Nova 2005, 28, 968.

23. Fitzgerald, W. F.; Gill, G. A.; Anal. Chem. 1979, 51, 1714

24.www.atmospheric-research.com/WebSOPs/Tekran\%202537 Course/2537_2_User_Course_Low_Values.ppt, accessed in November 2007

25. StatSoft; STATISTICA (data analysis software system), Version 7.0, ed. 2004.

26. Gill, G. A.; Guentzel, J. L.; Landing, W. M.; Pollman, C. D.; Water, Air, Soil Pollut. 1995, 80, 235.

27. Miller, L. C.; Miller, J. N.; Statistics for Analytical Chemistry; $3^{\text {rd }}$ ed.; Ellis Horwood Limited, Chichester, 1993

28. Ebinghaus, R.; Kock, H. H.; Jennings, S. G.; Mccartin, P.; Orren, M. J.; Atmos. Environ. 1995, 29, 3333.
29. Amouroux, D.; Wasserman, J. C.; Tessier, E.; Donard, O. F. X.; Environ. Sci. Technol. 1999, 33, 3044.

30. Fadini, P. S.; Jardim, W. F.; Sci. Total Environ. 2001, 275, 71.

31. Artaxo, P.; de Campos, R. C.; Fernandes, E. T.; Martins, J. V.; Xiao, Z. F.; Lindqvist, O.; Fernandez-Jimenez, M. T.; Maenhaut, W.; Atmos. Environ. 2000, 34, 4085.

32. Keeler, G.; Barres, J.; Sampling and Analysis for Atmospheric Mercury, Center for Environmental Research Information, Cincinati, 1999.

33. Sallsten, G.; Nolkrantz, K.; Analyst 1998, 123, 665.

34. Aeschliman, D. B.; Norton, G. A.; Environ. Sci. Technol. 1999, $33,2278$.

35. Hacon, S.; Artaxo, P.; Gerab, F.; Yamasoe, M. A.; Campos, R. C.; Conti, L. F.; Delacerda, L. D.; Water, Air, Soil Pollut. 1995, $80,273$.

36. Marins, R. V.; de Andrade, J. B.; Pereira, P. A. D.; Paiva, E. C.; Paraquetti, H. H. M.; Otimização de Amostrador de Mercúrio nas Fases Vapor e Particulado Atmosférico, CETEM, Rio de Janeiro, Brazil, 1999.

37. Marins, R. V.; Imbassay, J. A.; Pfeiffer, W. C.; Bastos, W. R. In Poconé: Um campo de Estudos do Impacto Ambiental do Garimpo; Veiga, M. M.; Fernandes, F. R. C., eds., CETEM, Rio de Janeiro, Brazil, 1991.

38. Lodenius, M.; Malm, O.; Rev. Environ. Contam. Toxicol. 1998, $157,25$.

39. Magarelli, G.; Fostier, A. H.; Atmos. Environ. 2005, 39, 7518.

Received: November 21, 2007 Web Release Date: August 8, 2008 